\title{
Uma revolução conservadora dos intelectuais (Brasil/2002-20l6)
}

Lidiane Soares Rodrigues'

\begin{abstract}
Quanto mais grosseiras são as produções do espírito estudadas pela Sociologia, tanto mais finos precisam tornar-se os procedimentos que visam dar conta dos efeitos de tais fenômenos.
\end{abstract}

(Theodor Adorno)

Apesar da ditadura de direita, há relativa hegemonia cultural de esquerda no país.

(Roberto Schwarz)

\section{Resumo}

Desde 2002, um mercado de reações às gestões presidenciais petistas estabeleceu-se, tanto por meio dos suportes das mídias convencionais mescladas às ultra contemporâneas quanto da produção social de intelectuais duplamente híbridos: trata-se de jornalistas-professores e de professores-jornalistas. Este artigo pretende caracterizar a dinâmica das trocas estabelecida entre os agentes desse mercado. O foco incidirá sobre Olavo de Carvalho; Demétrio Magnoli; Marco Antonio Villa; Reinaldo Azevedo; Luiz Felipe Pondé; Rodrigo Constantino; Leandro Karnal. A análise se desenvolverá em três movimentos: apresentará as classificações, os enquadramentos e algumas demandas que eles têm recebido por parte de adversários, contratantes e clientelas. Em seguida, realizará a sociogênese do espaço e dos agentes, resultantes da estruturação do sistema nacional ensino e de pesquisa, assim como da indústria cultural, ocorridos desde os anos 1970, a fim de caracterizar o princípio gerador de suas tomadas de posição políticas e culturais. Por fim, discutirá o enquadramento sociológico adotado.

Palauras-chave: Campo intelectual. Mercado de trocas simbólicas. Mídias. Indústria Cultural." Nova Direita".

1 Doutora em História Social pela Universidade de São Paulo (USP), professora adjunto do Departamento de Ciências Sociais da Universidade Federal de São Carlos (DCSo/UFSCar). Este trabalho apresenta resultados iniciais de projeto financiado pelo CNPq Universal/Fevereiro, 2016 (Processo 401043/2016-9). Agradeço à agência por esse benefício, a Dimitri Pinheiro, pelas finas sugestões, e a meus alunos de graduação em ciências sociais, que se aventuraram nessa pesquisa em 2016. Commons. Com essa licença você pode compartilhar, adaptar, para qualquer fim, desde que atribua a autoria da obra, forneça um link para a licença, $e$ indicar se foram feitas alterações. 


\section{Introdução}

A conquista da Presidência da República pelo Partido dos Trabalhadores (PT) e suas três vitórias eleitorais sucessivas em âmbito federal (2006, $2010,2014)$ provocaram uma reviravolta na topografia política. Enquanto uma esquerda histórica, mediante exercício do poder executivo, transformou-se em "situação", as direitas, ao lado das demais fraçôes da esquerda, assumiram a "oposição". Na esfera política, os partidos aliados e concorrentes do PT, e, na esfera cultural, os intelectuais e artistas, históricos apoiadores do PT ou críticos dele, foram instados a redefinir suas maneiras de intervenção face às posições políticas disponíveis. Este artigo trata de um setor particular da reconfiguração do trabalho de dominação política e produção simbólica daí oriunda - a saber: um mercado de reaçôes às gestôes petistas, estabelecido tanto por meio dos suportes das mídias convencionais mescladas às ultracontemporâneas quanto da produção social de figuras duplamente híbridas ${ }^{2}$. Os intelectuais que ofertam essas reaçôes são jornalistas-professores e professores-jornalistas (Quadro 1) 3 $^{3}$ Uns são jornalistas de profissão, outros têm praticado o colunismo/comentarismo político, mas se originam do sistema superior de ensino, do segmento das humanidades.

2 Este artigo adota uma abordagem sociológica de temas que têm sido tratados por duas outras áreas: comunicação e ciência política. Por adotar essa perspectiva, contudo, prefere empregar o termo mais neutro - "recursos digitais" e web - a fim de evitar a carga das tomadas de posição conceituais implicadas em "cyberespaço", "blogosfera" e tantos outros, que dizem respeito àquelas áreas. Do mesmo modo, realizará a sociogênese tanto dos agentes quanto das classificações - tomando relativa distância dos estudos politológicos que partem delas sem colocá-las em suspensão.

3 Esta afirmação se baseia no Quadro 2, que sumariza os percursos prévios e as posições atuais. 
Quadro I - Duplos híbridos: jornalistas-professores e professores-jornalistas

\begin{tabular}{|c|c|c|c|}
\hline Nomes e Tipos & Formação acadêmica & Atuação & $\begin{array}{l}\text { Rivais enunciados } \\
\text { (não exaustivo) }\end{array}$ \\
\hline $\begin{array}{l}\text { Olavo de Carvalho } \\
\text { (Campinas/SP, 1947) } \\
\text { Jornalista-Professor }\end{array}$ & $\begin{array}{l}\text { Filosofia (bacharelado } \\
\text { não concluído no } \\
\text { Conpefil da PUC-RJ) } \\
\text { Concepção do curso de } \\
\text { Astrologia da PUC-SP } \\
\end{array}$ & Jornalismo & $\begin{array}{l}\text { Leandro Konder; } \\
\text { Marilena Chauí; } \\
\text { Emir Sader }\end{array}$ \\
\hline $\begin{array}{l}\text { Demétrio Magnoli } \\
\text { (?/1958) } \\
\text { Jornalista-Professor }\end{array}$ & $\begin{array}{l}\text { Jornalista (USP) } \\
\text { Geografia } \\
\text { (Doutorado/USP) }\end{array}$ & $\begin{array}{l}\text { Jornalista } \\
\text { Autor de livros paradidáticos } \\
\text { de Geografia e História. }\end{array}$ & $\begin{array}{l}\text { Marilena Chauí; } \\
\text { Renato Janine Ribeiro; } \\
\text { Emir Sader; } \\
\text { Hebe Matos }\end{array}$ \\
\hline $\begin{array}{l}\text { Marco Antonio Villa } \\
\text { (São José do Rio } \\
\text { Preto/SP, 1955) } \\
\text { Professor-Jornalista }\end{array}$ & $\begin{array}{l}\text { Bacharel, Licenciado em } \\
\text { História (USP) } \\
\text { Mestre em Ciências } \\
\text { Sociais } \\
\text { Doutor em História } \\
\text { Curso de Economia não } \\
\text { concluído na PUC-SP } \\
\end{array}$ & $\begin{array}{l}\text { Professor do ensino médio; } \\
\text { Professor do curso de } \\
\text { História da UFOP (1985- } \\
\text { 1994) e de Ciências Sociais } \\
\text { da UFSCar (1995-2013). } \\
\text { Autor de livros didáticos/ } \\
\text { paradidáticos. }\end{array}$ & $\begin{array}{l}\text { Marilena Chauí; } \\
\text { Marco Aurélio Garcia; } \\
\text { Renato Janine Ribeiro; } \\
\text { Fernando Haddad }\end{array}$ \\
\hline $\begin{array}{l}\text { Reinaldo Azevedo } \\
\text { (Dois Córregos/SP, } \\
\text { 1961) } \\
\text { Jornalista-Professor }\end{array}$ & $\begin{array}{l}\text { Jornalismo (Universidade } \\
\text { Metodista). } \\
\text { Foi aluno dos cursos de } \\
\text { Letras (USP). }\end{array}$ & Jornalista & $\begin{array}{l}\text { "Bonde do Foucault"; } \\
\text { Marilena Chauí }\end{array}$ \\
\hline $\begin{array}{l}\text { Luiz Felipe Pondé } \\
\text { (Recife/PE, 1959) } \\
\text { Professor-Jornalista }\end{array}$ & $\begin{array}{l}\text { Filosofia "Pura” (USP) } \\
\text { Medicina (UFBA) }\end{array}$ & $\begin{array}{l}\text { Professor do Departamento } \\
\text { de Teologia da PUC-SP } \\
\text { e do Departamento de } \\
\text { Humanidades da FAAP-SP. }\end{array}$ & $\begin{array}{l}\text { "Marxistas" } \\
\text { "Marxismo } \\
\text { foucaultiano" }\end{array}$ \\
\hline $\begin{array}{l}\text { Rodrigo Constantino } \\
\text { (Rio de Janeiro/RJ, } \\
\text { 1976) } \\
\text { Não se aplica } \\
\end{array}$ & $\begin{array}{l}\text { Economia (Formado } \\
\text { pela PUC-RJ; MBA em } \\
\text { Finanças/IBMEC) }\end{array}$ & $\begin{array}{l}\text { Setor financeiro e em think } \\
\text { tanks. }\end{array}$ & $\begin{array}{l}\text { Vladimir Safatle; } \\
\text { Miriam Leitão }\end{array}$ \\
\hline $\begin{array}{l}\text { Leandro Karnal } \\
\text { (Rio Grande do Sul/ } \\
\text { São Leopoldo, 1963) } \\
\text { Professor-Jornalista }\end{array}$ & $\begin{array}{l}\text { História (Universidade do } \\
\text { Cale do Rio dos Sinos- } \\
\text { UNISINOS/RS) } \\
\text { Graduação 1985_ } \\
\text { Doutorado em História } \\
\text { (USP, 1994) }\end{array}$ & $\begin{array}{l}\text { Professor de ensino médio } \\
\text { em escolas públicas e } \\
\text { particulares; } \\
\text { Professor (1998 } \\
\text { - atualmente) do } \\
\text { Departamento de História } \\
\text { da Unicamp. } \\
\text { Trabalhou no Instituto } \\
\text { Cultural Banco de Santos. }\end{array}$ & - \\
\hline
\end{tabular}


O artigo trata do mercado de reaçóes constituído por Olavo de Carvalho; Demétrio Magnoli; Marco Antonio Villa; Reinaldo Azevedo; Luiz Felipe Pondé; Rodrigo Constantino; Leandro Karnal. Em primeiro lugar, em uma perspectiva sincrônica, apresenta as classificaçóes, os enquadramentos e algumas demandas que eles têm recebido, respectivamente, por parte de adversários, contratantes e clientelas (itens 1 a 3). Em seguida, diacronicamente, ocupa-se da sociogênese do espaço e dos agentes, resultantes da estruturaçáo do sistema ensino e da indústria cultural, ocorrido nos anos 1970. Trata-se de caracterizar, estruturalmente, o princípio gerador de suas tomadas de posição e ambiçóes de legislação a respeito do arbitrário cultural e político (item 4). Por fim, com o objetivo de situar-se no interior da discussão de dois eixos especializados da sociologia da cultura - o da indústria cultural e o dos intelectuais - discute o entrelaçamento deles, subjacente à abordagem desenvolvida neste artigo.

\section{Posições, agrupamentos, oposições}

Assumindo que a organização social subjaz às categorias lógicas e classificatórias, os princípios de visão e de divisão, cindindo "eles de nós", têm origem no conjunto das posiçóes ocupadas pelos agentes que as elaboram, consideradas umas em relação às outras. A seguir, algumas categorias classificatórias empregadas para agrupá-los.

Quadro 2 - Formas de classificação

\begin{tabular}{|c|c|c|c|}
\hline & Classificação & Classificadores & Classificados \\
\hline p- & $\begin{array}{l}\text { Extrema direita } \\
\text { Brasil de fato, 28/09/2010 }\end{array}$ & $\begin{array}{l}\text { Jornalismo } \\
\text { Mario Augusto } \\
\text { Jakobskind }\end{array}$ & $\begin{array}{l}\text { Olavo de Carvalho, Reinaldo } \\
\text { Azevedo, Diego Mainardi, Arnaldo } \\
\text { Jabor }\end{array}$ \\
\hline p- & $\begin{array}{l}\text { Novos trombones da direita; } \\
\text { neocons à brasileira } \\
\text { Revista Época, 19/04/2012 }\end{array}$ & $\begin{array}{l}\text { Jornalismo } \\
\text { Paulo Nogueira }\end{array}$ & $\begin{array}{l}\text { Denis Lerrer Rosenfield, Luiz Felipe } \\
\text { Pondé, João Pereira Coutinho, Marco } \\
\text { Antonio Villa, Demétrio Magnoli, } \\
\text { Rodrigo Constantino. }\end{array}$ \\
\hline * & $\begin{array}{l}\text { Direita hidrófoba } \\
\text { O Globo, 03/11/2013 }\end{array}$ & $\begin{array}{l}\text { Jornalismo } \\
\text { Miriam Leitão }\end{array}$ & $\begin{array}{l}\text { Reinaldo de Azevedo ; Rodrigo } \\
\text { Constantino }\end{array}$ \\
\hline p- & $\begin{array}{l}\text { Colunistas conservadores } \\
\text { Isto é, } 04 / 1 \text { I/2013 }\end{array}$ & $\begin{array}{l}\text { Jornalismo } \\
\text { Paulo Moreira Leite }\end{array}$ & $\begin{array}{l}\text { Reinaldo Azevedo, Demétrio } \\
\text { Magnoli, Rodrigo Constantino }\end{array}$ \\
\hline
\end{tabular}




\begin{tabular}{|c|c|c|c|}
\hline & Classificação & Classificadores & Classificados \\
\hline p- & $\begin{array}{l}\text { Pupilos de OC } \\
\text { Diário do Centro do Mundo, } \\
\text { 13/04/2015 }\end{array}$ & $\begin{array}{l}\text { Jornalismo } \\
\text { Paulo Nogueira }\end{array}$ & $\begin{array}{l}\text { Kim Kataguiri, Danilo Gentili, Lobão, } \\
\text { Pastor Everaldo, Roger do Ultraje, } \\
\text { Rodrigo Constantino, Rachel } \\
\text { Sheherazade }\end{array}$ \\
\hline e- & $\begin{array}{l}\text { Intelectuais midiáticos } \\
\text { Observatório da imprensa, } \\
\text { 12/01/2016 }\end{array}$ & $\begin{array}{l}\text { Jornalismo } \\
\text { Francisco } \\
\text { Fernandes Ladeira }\end{array}$ & $\begin{array}{l}\text { Demétrio Magnoli, Marco Antonio } \\
\text { Villa, Luiz Felipe Pondé }\end{array}$ \\
\hline e+ & $\begin{array}{l}\text { maiores pensadores } \\
\text { contemporâneos do Brasil } \\
\text { Isto é, } 07 / 10 / 2016\end{array}$ & $\begin{array}{l}\text { Jornalismo } \\
\text { Fabíola Perez }\end{array}$ & $\begin{array}{l}\text { Leandro Karnal, Mario Sérgio } \\
\text { Cortella, Clóvis de Barros Filho }{ }^{4}\end{array}$ \\
\hline e- & $\begin{array}{l}\text { Celebridade } \\
\text { GGN, 15/03/2017 }\end{array}$ & $\begin{array}{l}\text { Jornalismo } \\
\text { Luis Nassif }\end{array}$ & Leandro Karnal, Roberto Da Matta \\
\hline
\end{tabular}

Fonte: Elaboração própria

Nota: Na tabela, a coluna à esquerda, com (e) e (p), indicam, respectivamente, critério econômico e politico de classificaçâo; os sinais (-) (+) indicam, respectivamente atribuiçōes negativas e positivas a esses critérios. O sinal $\left(^{*}\right)$ indica que o texto não se enquadra nestes termos. ${ }^{5}$

Embora os jornalistas não sejam seus adversários declarados, estes profissionais reagem imediatamente a eles, posto que sejam atingidos imediatamente por suas intervençóes (EYAL, BUCHOLZ, 2010). A reação à contratação de Reinaldo Azevedo pela Folha de S. Paulo (FSP) em 2013, é ainda mais expressiva:

[...] a Folha anunciou a contratação de um rottweiler. O feroz Reinaldo Azevedo estreou disparando [...] A contratação de Reinaldo é coerente com o 'saco de gatos' da Folha, Os novos nomes... vão engrossar o já extenso plantel de colunistas do jornal. São hoje 102, provavelmente um recorde mundial. Não dá para fazer um censo ideológico de tanta gente... A Secretaria de Redação diz que "o jornal não pensa em colunistas em termos de esquerda e direita ... No atual momento da mídia, em que boa parte do noticiário está de graça na internet e no qual falta dinheiro para expandir as equipes de reportagem, aumentar o espaço destinado à opinião tem sido uma forma de tentar diferenciar-se [...] a Folha almeja tornar-se a principal arena de debate

4 Trata-se da única categorização positiva e destituida de teor concorrencial (ideológico e profissional). De todo modo, ela se apresenta no formato de matérias de encomenda, como "Eles fazem a cabeça dos jovens". (PEREZ, 20I8).

5 Na fase de elaboração do projeto de pesquisa (em 2014-2015), as classificações foram utilizadas para delimitar a seleção dos agentes; cotejando-as com as referências de uns aos outros (positivas e negativas) - os mais citados uns pelos outros e "classificados" (acima, sublinhados) foram dando os contornos do conjunto. 
político em 2014, ano de campanha eleitoral. Para que o leitor seja de fato beneficiado por isso, será preciso garantir um bom nível de "conversa"... no impresso, espera-se mais_argumento e menos estridência. Mais substância, menos espuma. Do contrário, a Folha estará apenas fazendo barulho e importando a selvageria que impera no ambiente conflagrado da internet. (Suzana Singer (2013), ombudsman da FSP até abril/2014, grifo nosso).

O Brasil não está ficando burro. Mas parece, pela indigência de certos debatedores que transformaram a ofensa e as agressões espetaculosas em argumentos. Por falta de argumentos. Esses seres surgem na suposta esquerda, muito bem patrocinada_pelos anúncios de estatais, ou na direita hidrófoba que ganha cada vez mais espaço nos grandes jornais. (Miriam Leitão (2013), jornalismo econômico, grifo nosso).

O tom cioso da respeitabilidade do jornalismo político impresso, o rechaço à submissão do jornal às injunções puramente econômicas, e a denúncia do risco de desclassificação deixam evidentes as motivações profissionais em jogo. O rebaixamento do jornalista ao animal/inumano e violento/irracional ("feroz", "disparando") corresponde à degradaçáo do periódico ao nível da incongruência ("saco de gatos"). A FSP, deste ponto de vista, reproduz, sem mediação, a "selvageria", "estridência" das opiniôes "sem substância" da web. A tentativa de recuperação do brio da posição profissional é tangível no reclame de que sob a nobre bandeira do "pluralismo", a FSP é movida pela ambição econômica de atender à heterogeneidade do mercado de consumidores/assinantes. Também Miriam Leitão chama atenção para perda de nível (indigência) e de inteligência, em função da chancela ao baixo nível de estratégias de mercado (violência, ofensas, agressóes) ${ }^{6}$ - que acomodam esquerda e direita. Efetivamente, o caso exemplifica que, como tantos outros domínios, o jornalismo, em sua gênese, apresentou conflitos entre os princípios de orientaçáo do polo puro e de polo comercial - que se repóem estruturalmente (BOURDIEU, 1997) e cujo equilíbrio varia segundo sua crescente segmentação e intercâmbio com outros campos (DUVAL, 2004). O princípio gerador dessas categorizaçóes resulta da concorrência profissional e/ou ideológica - tal como ela se configura no jornalismo atualmente.

Essas não são as únicas práticas de classificação e agrupamento a que estão submetidos. Os contratantes agrupam-nos segundo os princípios da

6 Cumpre esclarecer que o tratamento completo do quadro requer a apresentação das posições dos "classificadores" no campo do jornalismo, mas isso prejudicaria o foco deste artigo. 
gestão dos recursos da indústria da informação e do entretenimento - que dispôe de recursos convencionais (televisão, rádio, jornalismo impresso) combinados aos do universo digital (blogs, canais no youtube, contas em redes sociais, como facebook e twitter), para uma vasta difusão e repetição das mensagens, e para o alcance de públicos diferenciados e dispersos geograficamente. Esses indivíduos, situados em posiçóes equivalentes, justapostas em série, ofertando sentidos, por meio de suas reaçóes individuais à conjuntura política, e, particularmente, às gestóes petistas configuram um "mercado de reaçóes" (BOURDIEU, 1996, HIRSCHMAN, 1992). ${ }^{7}$

O terceiro tipo de classificação/agrupamento tem origem na relação que esses intelectuais logram estabelecer com o público. A heterogeneidade sociológica da clientela, auto classificada segundo os modos de adesão (fãs, seguidores, admiradores, ouvintes, telespectadores, leitores e alunos) e os veículos que usam (convencionais e web) condicionam apropriaçóes diferenciadas e relativamente imprevisíveis das mensagens e das "fachadas pessoais” (GOFFMAN, 2005)․ Por isso, as mesmas estratégias (discursivas e

7 Três indicações bastam para esquadrinhar o espaço social alargado à disposição desses intelectuais e seus nexos com a mixagem de recursos convencionais e ultracontemporâneos. Em primeiro lugar, os casos do jornalismo impresso, recém- ingressos no mercado das versões digitais (pagas e não pagas) e canais virtuais (de acesso liure) - como a Veja e a FSP. Estas empresas criaram séries e programas emitidos na web: "TV Folha. Comenta que eu te escuto" (em que colunistas da FSP reagem oralmente aos comentários enviados por escrito por seus leitores); "TVeja. I minuto com Augusto Nunes" (em que o apresentador entrevista os colunistas da revista - a seguir, episódio I). O conteúdo é parte da estratégia de marketing do próprio periódico, na medida em que exploram a imagem de seus colunistas e jornalistas, concomitantemente à campanha por assinaturas. Em segundo lugar, identificam-se também os casos do jornalismo radiofônico, que investem na difusão na web por meio de canal aberto - como é o caso da Jovem Pan On line e da Band News FM (a seguir, episódios 3 e 4). Além dessas empresas de comunicação, espaços de cultura grã-finos e populares - como a Casa do Saber ("O youtube virou a Casa do Saber") e o SESC (Serviço Social do Comércio) - também se valem do entrelaçamento dos veículos convencionais e digitais para capilarização de atividades. Finalmente, identificam-se parcerias entre empresas de televisão, empresários, governos e espaços de cultura - como é o caso do programa "Café Filosófico", patrocinado pela Companhia Paulista de Força e Luz (CPFL), gravado pela TV Cultura e realizado em espaço cedido pela prefeitura de Campinas (episódio 5). Os indivíduos em questão podem ser contratados por essas empresas (públicas, ligadas ao governo do Estado de São Paulo, como Fundação Padre Anchieta/TV Cultura; ou privadas, como as demais) ou colaborarem esporadicamente sem contrapartida econômica imediata (em programas de auditório e de entrevistas, por exemplo). Igualmente, eles combinam recursos convencionais e digitais: escrevem liuros, colunas, debatem em rádio e também possuem blogs, canais no youtube, contas em redes sociais (episódio 2). Alguns terceirizam o gerenciamento da identidade digital e outros aproveitam o trabalho não pago realizado por "fãs/seguidores" que criam páginas (dedicadas, em geral, a um deles; não ao conjunto), com o objetivo de "homenageá-los".

8 Embora Goffman tenha formulado a ideia para tratar das interações face a face, alude-se a ela a fim de salientar esse ponto. A análise do nexo entre as fachadas pessoais, o conteúdo das mensagens, e os públicos preferenciais desviaria o foco da caracterização do "mercado de reações". 
atitudinais) podem implicar ganhos e/ou perdas na disputa pela freguesia9

A seguir, são apresentados 5 episódios, exemplares da tensão entre identificação e diferenciação (entre eles, e deles em relação a personalidades políticas). A linha divisória, do ponto de vista cultural e ideológico, só se estabelece depois do constrangimento a "prestar contas", condicionado por agrupamentos realizados por meio de um princípio compartilhado. Por exemplo: o "antipetismo" (nos episódios 1 e 4, emparelha Villa a Olavo de Carvalho e a Bolsonaro); a denúncia da presença do marxismo e da cultura de esquerda nas universidades (no episódio 2, agrupa Pondé e Olavo de Carvalho), a ironização das reivindicaçôes de minorias e da "patrulha ideológica" do "politicamente correto" (no episódio 3, aproxima Pondé e Bolsonaro; no 2, Pondé de Olavo Carvalho). As apropriações são marcadas por decalagens diversas entre a mensagem emitida e a recebida, sendo os princípios da recepçáo determinados pelas demandas opacas, endereçadas por clientelas parcialmente desconhecidas. Nos episódios em que eles procuram se diferenciar uns dos outros (episódios 1 e 2), nos que tomam distância da tradução política de suas mensagens (episódio 3 e 4), e nos em que se alinham (episódio 2 e 5) ${ }^{10}$, eles perdem e/ou ganham freguesia.

Episódio I. Marco Antonio Villa e Olavo de Carvalho. Nas manifestações de rua ocorridas em 15/03/2015 e 12/04/2015, a favor do impeachment de Dilma Rousseff, havia manifestantes com faixas nas quais se lia: "Olavo tem razão". No programa da TV Veja, na web, Villa reagiu ${ }^{\prime \prime}$ :

[...] tem muito bobo que critica o atual governo e não sabe nada, [...] eles fazem programinha e colocam no youtube [...] vi até cartazes em manifestação [...] então é importante a gente separar o joio do trigo, eu por exemplo não estou com esses caras [...] , tem um que é até astrólogo tal [...]

9 Saliente-se que os outros dois não são indiferentes a ela - e que as categorizações injuriosas ou interessadas (acima) dirigem-se a eles e parcialmente a seus públicos: seus adversários percebem o risco de perder público para eles; seus contratantes percebem-nos como ativos para a ampliação de clientes. A lógica das trocas, inversa à do polo erudito e restrito da produção cultural confere centralidade à freguesia e às práticas de conversão dela (BOURDIEU, 2003b).

10 Como o episódio 4 exprime de modo típico esta lógica, optamos por apresentá-la por meio dele. A transcrição das reações de todos os episódios seria redundante.

$1 /$ As imagens de cartazes com o nome de Olavo, nas manifestações de rua, como em: BRASIL (2017). A participação foi registrada: <https://www.youtube.com/watch?v=dGAYBBduexc>. (14/12/2015); <https://www. youtube.com/watch?v=2-s0r3X2Icg (16/08/2015)>; e <https://www.youtube.com/watch?v=FuwOLgwLkEo> (13/03/2016). 
[...] ideólogos medíocres que se intitulam até filósofos, quando não são nada, filósofo em campo do quê, aonde escreveu (sic), aonde é citado, qual é a sua formação, é bacharel, fez mestrado, fez doutorado, são embusteiros que enganam pessoas num país (...) de um baixo nível (...) gente que passou até pela astrologia e hoje se diz líder político [...] (VILLA, 2015, grifos nossos).

Comentário: os termos dessa tomada de distância implicam diferenciar-se de modo a cativar uma clientela que se pretenda "não boba"; "não medíocre"; "discernida" (capaz separar joio do trigo). No mesmo certame, Villa distinguia comunismo de esquerda e PT de comunismo, concluindo: "o PT não é comunista". Do ponto de vista dos "olavetes" (seguidores de Olavo de Carvalho), que são a favor da identificação PT/comunismo/esquerda, isso bastou para que Villa fosse classificado como "petista"; já do ponto de vista de Rodrigo Constantino (2015), a avaliação foi outra: "tudo que não precisamos agora é um racha entre os antipetistas".

Episódio 2. Luiz Felipe Pondé e Olavo de Carvalho. Em seu canal pessoal no youtube (vídeo de 06/06/2016), Pondé respondeu à pergunta: quais suas relações com Olavo de Carvalho? Na transcrição a seguir - diga-se de passagem, maneira imperfeita de apresentar o material pois permite a apresentação da prosódia, repleta de entrecortados dramáticos chama-se a atenção (nos negritos) para a elevação das fórmulas de apreciação emparelhadas às marcas rebaixadas de expressão (em itálico).

O Olavo de Carvalho é uma figura bastante importante na história do pensamento público brasileiro, tem o papel fundamental de ter sido o primeiro... que teve coragem de apontar os erros metodológicos e o domínio intelectual que a esquerda exercia... (e) a canalhice muitas vezes envolvida... ele também tem a virtude de ter aberto os horizontes de uma bibliografia mais digamos grosso modo liberal conservative que o Brasil não tinha acesso, inclusive indicando títulos para serem traduzidos no Brasil também tem a virtude de ter preparado muitos jovens para enfrentar o domínio da esquerda... figura importante na história do pensamento não-de-esquerda no Brasil... nossos estilos são muito diferentes... eu não tenho nenhuma relação com nenhum conjunto dogmático de fé religiosa... digamos assim grosso modo... a gente tem uma concordância (na) abertura da bibliografia para temas não só do universo marxista foucaultiano (e) também no sentido de pensar que o PT seja uma catástrofe para história da cultura do país e para a história da política mas é até aí onde (sic) vão nossas semelhanças... nós temos um estilo diferente de ver o mundo,... eu sou alguém digamos assim... com carreira na universidade... enquanto que o Olavo fez a maior parte da sua carreira fora desse universo, nem por isso menos em termos de conteúdo e de capacidade intelectual, sem dúvida, mas aí eu acredito que tem essas diferenças e principalmente eu diria diferenças com relação àqueles que são meus alunos e são alunos do Olavo... eu tenho um universo 
de interesses que vão muito além do debate político... existem mais diferenças do que semelhanças entre o meu pensamento e o do Olavo... (PONDÉ, 2016, grifos nossos).

Comentário: as fórmulas e os critérios de apreciação mobilizados para enobrecer Olavo de Carvalho, correspondem, por um lado, aos da Filosofia enquanto disciplina de erudição (Rodrigues, 2018). Diga-se de passagem, o emprego do termo "alunos", para seus seguidores na web, eleva ambos (Pondé e Olavo de Carvalho). Por outro lado, a introdução de termos“baixos" (canalhice, animal) e o descompromisso com a língua acadêmica elevada (mesmo em versão oral), corresponde ao padrão exigido pela comunicação nos meios mixados e em fluxo. $\mathrm{O}$ caso corresponde à emulação do polo erudito, realizada pelo polo de produção alargado e comercial (indústria cultural) (BOURDIEU, 2003b) ${ }^{12}$. O teor dos 2088 (consulta em 03/07/2018) comentários suscitados pelo vídeo cuja transcrição parcial se apresentou deixa patente que eles possuem fraçóes de clientela convergentes. Se há alguns que preferem um em detrimento do outro, tudo transcorre como se os consumidores de um fossem potencialmente também do outro. De todo modo, essa prestação de contas patenteia o empenho em realçar as diferenças, situando-se contra as aproximaçóes imputadas pela clientela, insistindo em suas diferenças de pertencimento ("sou acadêmico versus ele não”). Sendo permanente a reação ao vídeo - cumpre sublinhar - pode ser impactada por outras tomadas de posiçáo. Isso fica evidente adiante, no diálogo entre dois seguidores. Enquanto um (Internauta A) aposta na aproximação de Pondé e Olavo de Carvalho, lendo livros dos dois, mas reprovando a conduta do primeiro em relação a Bolsonaro (ver episódio 3); o outro (Internauta B) reconhece sinal de "esquerdismo" na distância que Pondé toma do então pré-candidato. (A seguir, o Internauta $\mathrm{B}$ responde ao $\mathrm{A}$. As imagens e nomes foram eliminados para resguardar suas identidades).

12 Vale assinalar que a esta mixagem pontilha as estratégias todos os individuos em questão. Por exemplo: Reinaldo Azevedo destacou-se por escrever com letras vermelhas e em caixa alta - equivalente, em linguagem oral, a gritos. Paralelamente, a este recurso "baixo", mobiliza referências literárias, repertório possivelmente adquirido no curso não concluido de Letras da USP - naturalmente, sem oferecer a referência ao leitor comum. favorecendo o senso de distinção do leitor mais ambicioso culturalmente. 
Internauta A.

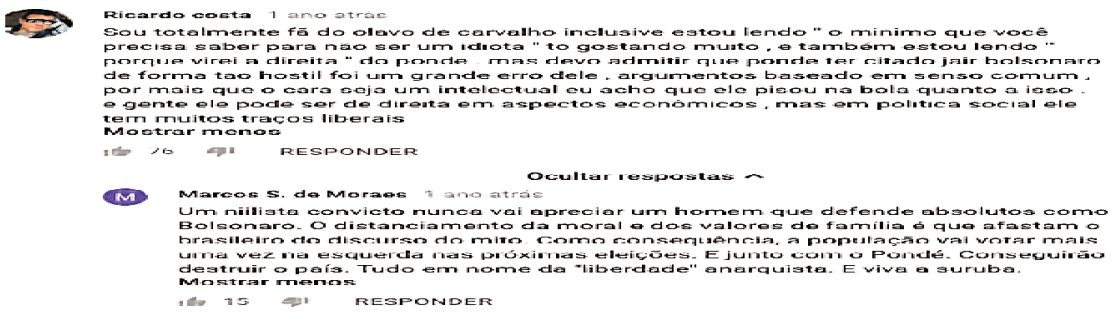

Internauta B.

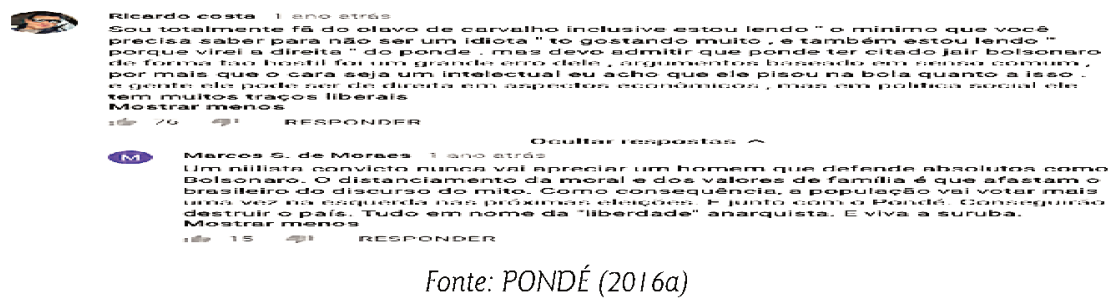

Episódio 3. Luiz Felipe Pondé e Jair Bolsonaro. Pondé foi instado pela Rádio Bandeirantes a avaliar as opiniões de "Jair Bolsonaro e seus eleitores". Ele afirmou: ele tem uma fala associada a grupos... que se sentem ameaçados [...] ele representa [...] uma expectativa de política bastante simplista [...] de certa forma em que essa confusão que é a democracia, esses grupos de embate um com o outro [...] que o senso comum não consegue capturar e tem um desejo que seja colocado alguém lá para resolver o problema [...] esta questão [...] minorias, parada gay alimenta o universo do imaginário de eleitores do Bolsonaro. (PONDÉ, 2017, grifos nossos).

Comentário: esta demanda endereçada pela Rádio se deve ao conteúdo ideológico que distingue Pondé: os rechaços ao feminismo e às reivindicaçóes das "minorias" (sua marca exclusiva, não encontrada nos demais indivíduos em análise). Por isso, Bolsonaro poderia ser associado a ele por causa de sua homofobia e antifeminismo. A estratégia da tomada de distância de Bolsonaro é similar à de Villa (episódios 1 e 4): elevar-se por meio do rebaixamento das capacidades intelectuais do outro ("simplista", "nấo consegue captar"). A recepção fica dividida não apenas quanto à "aprovação" 
ou "reprovação", mas quanto ao princípio: enquanto um (Internauta A, episódio 2), adota a métrica da autoridade simbólica para retirar legitimidade dela ("por mais que o cara seja um intelectual, pisou na bola [rebaixando Bolsonaro]"); seu interlocutor adota o princípio político de classificação (opor-se a Bolsonaro é ser de esquerda). No episódio a seguir, a tensão entre demanda por autoridade intelectual e denegação do exercício dela, manifesta-se de modo exemplar.

Episódio 4. Marco Antonio Villa (MAV) entrevistou Jair Bolsonaro (JB). Durante 40 minutos, ambos falaram, exaltados no tom de voz, sem que houvesse pausa ou término da formulação das perguntas e das respostas. Observe-se um trecho do embate: MAV. Economia não deu ... relações exteriores também não. JB. Você está querendo tirar de mim, você quer tirar o quê? MAV. Só tô trocando umas ideias com o senhor. JB Mas cê quer tirar o quê. MAV. É que o senhor, como candidato a presidente do Brasil... JB. Não sou candidato. MAV. O sr. é pré candidato. JB [...] o sr. quer em 30 minutos, em alguns minutos quer que eu resolva o problema econômico do Brasil?... MAV. Eu quero que o sr. dê substância à sua fala... JB. Eu tenho direito de responder de outra forma ou cê quer que eu seja igual você. MAV. Não... eu queria que o sr. desse resposta consistente sobre indústria, serviço, agricultura. JB. Pera aí... o JB foi o único da base aliada que não foi comprado pelo PT. Isso não conta? [...] MAV. O sr. é a favor da bomba atômica? [...] e nós íamos jogar contra quem? (riso/ironia). JB. É igual uma arma, imagina uma arma na sua cintura. MAV. Mas pera aí, o sr. está armado? JB. Ué e se tivesse, eu tenho porte. MAV. Mas o sr. vem armado para um debate? JB. Eu tenho porte, quer pagar para ver? [...] MAV [...] o que me interessam são questões estruturais, o sr. tergiversa sempre para questões do campo moral, da honestidade [...] eu fiquei realmente impactado, deputado porque eu percebi que o sr., por um lado, não conhece a economia brasileira. JB. Eu não sou igual você. MAV. Não conhece os três setores da economia, a balança comercial [...] o que é um acordo bilateral [...] a questão do papel do Mercosul [...] para ser candidato [...] é necessário conhecimento sobre o Brasil, sair da esfera do panfleto. (JOVEM PAN NEWS, 2017).

As reaçóes ao episódio podem ser condensadas no depoimento de um fiel "seguidor":

(Villa foi) arrogante como jamais imaginei [...] tentou - e conseguiu - humilhar intelectualmente Bolsonaro [...] Foi agressivo, mal educado e por vezes um tirano [...] se a intenção de Villa era humilhar Bolsonaro e expor sua fragilidade intelectual, conseguiu com louvor. Se a intenção era tirar-lhe alguns votos, se lascou! Quem os ouviu ficou literalmente ao lado de Bolsonaro. (KERTZMAN, 2017).

Comentário: do ponto de vista dessa fração da clientela de Villa, ele deveria demonstrar, portanto: modéstia (oposta à arrogância); generosidade 
com a "fragilidade intelectual" (oposta à humilhação); delicadeza e educação (opostas à agressividade e tirania). Se a provocação a Jair Bolsonaro foi reconhecida como humilhação, essa clientela não é inteiramente alheia à hierarquia e à autoridade cultural. Ademais, se ela se identificou com Bolsonaro por causa dessa humilhação (tal qual o seguidor de Pondé e Olavo de Carvalho, no episódio 3) - então essa experiência lhe é familiar. A clientela experimenta tanto o apreço à autoridade intelectual quanto o insulto simbólico que ela pode lhe dirigir ao expor sua destituição de capital cultural.

Episódio 5. Leandro Karnal, Luiz Felipe Pondé e Mario Sergio Cortella realizaram um "Café Filosófico Especial”, a propósito do lançamento do livro Verdades e mentiras. Ética e democracia no Brasil - promovido pelo CPFL. Num palco, com três poltronas, após apresentá-los como "professor Cortella"/ "professor Pondé", com pausas para aplausos, gritos e assobios, Karnal, diz: "falta agradecer principalmente ... acho que é ao astro principal da noite que são todos vocês, que num dia de chuva forte, um certo frio, vem até esse espaço para ouvir falar de política, ética e filosofia, vocês [empenhando ao alto os dois braços, aponta com as duas mãos para o público] são o astro principal desta noite. [Aplausos dos convidados e da plateia]. (CPFL, 20I6).

Comentário: segundo a organização, tratou-se do maior público já reunido pelo "Café Filosófico": presencialmente, havia mais de 4300 pessoas; acompanhando pela web, havia 9 mil pessoas; pelo youtube, mais de 30 mil pessoas (o programa mais acessado do dia). Simulando uma palestra, o evento assumiu a forma de um programa de auditório (VOLPE, 2013). A abertura ocorreu com a chegada do palestrante/apresentador (Karnal), à qual se seguiram gritos e aplausos do público/plateia. As exposiçóes foram bem-humoradas, repletas de trocadilhos e piadas (com referências religiosas - vale dizer, Karnal, é especializado em história religiosa; Pondé e Cortella são professores do departamento de "Teologia e Ciências da Religião" da Pontifícia Universidade Católica (PUC-SP), sem explicitação nítida de divergências, e com passagens similares a "aulas expositivas". A plateia enviou perguntas por escrito (via chat), lidas por uma assistente de auditório. No conjunto, as perguntas tinham o feitio "dúvidas" e pedido de aconselhamento. Dado o formato do programa, as reaçóes às respostas não são possíveis e os "palestrantes" têm sempre a última palavra seguida de aplausos de fraçóes do público. O episódio também apresenta a aludida mixagem entre atributos alto/baixo dos bens simbólicos. Por exemplo: o 
livro lançado combina um título de teor melodramático (Verdades e mentiras) com um subtítulo similar ao de uma conferência acadêmica (Ética e democracia no Brasil). Esse ponto é desenvolvido a seguir.

\section{Alodoxia e hibridismo}

Os episódios de 1 a 4 deixam evidente que o encaixe entre a oferta e a demanda por "reaçôes"- que promove o encontro desses intelectuais com essas clientelas, mediado pelos contratantes (rádio, televisão, jornais, editoras) - não poderia ser compreendido segundo a razão escolástica, inclinada a supor que ele ocorra segundo princípios racionais ou de consistência ideológica.

Se a heterogeneidade da clientela é evidente nas apropriaçóes diferenciadas das mensagens, é tangível alguma homogeneidade em termos de déficit de capital cultural, particularmente em sua dimensão política (léxico, conceitos, conhecimento histórico). Como são destituídas desse recurso - e da socialização militante (modo por excelência de aquisiçâao dele pelas camadas médias), que garanta a incorporaçâo de condutas correlatas (como desenvoltura com as regras da subversão política; manejo na tomada da palavra, domínio de repertório intelectual, artístico, autoral etc.) - suas demandas podem ser satisfeitas com o que oferecem os espaços da mídia convencional mixados aos da web ${ }^{13}$. Habituadas à linguagem televisiva/web, elas são culturalmente mais disponíveis ao embaralhamento de gêneros, suportes (aulas, palestras, programas de auditório, debate, telejornalismo, entrevista) e de papéis (professores, jornalistas, conferencistas), tornando eficaz o serviço de dignificação sociocultural e de compensaçấo simbólica prestado por eles. $\mathrm{O}$ exame das reaçôes identifica a ambição de tomar a palavra/posiçóes no âmbito da política, de participar, e, simultaneamente, a inclinação à "alodoxia cultural" - explorada de modo programático pela publicidade, que "[...] valoriza a acessibilidade econômica e cultural dos produtos propostos, e, ao mesmo tempo, sua alta

13 A hipótese que orientou o argumento inspirou-se no modelo estrutural e quiasmático de Pierre Bourdieu (2007, esp. p. 4I2-434) e na observação das reações simultâneas da clientela à atuação dos indivíduos em questão no Jornal da TV Cultura, transmitido pela web (realizada entre dezembro/2015 e março/20 I 6 e, posteriormente, entre dezembro/2017 e abril/20/8). 
legitimidade pela invocação de autoridades culturais." (BOURDIEU, 2007, p. 533). Trata-se de mecanismos compensatórios ao reconhecimento opaco da emulação por parte da clientela e a seu senso de destituição (episódio 2).

Tanto os jornalistas (Reinaldo Azevedo, Demétrio Magnoli, Olavo de Carvalho) quanto os professores (Pondé, Karnal, Villa) desempenham funçôes paradidáticas. Os princípios de enquadramento mobilizados pelo jornalismo não poderiam ser mais expressivos: chamam suas exposiçóes de aulas, dirigem-se a eles como "professores" (exemplarmente: NUNES, 2017)

Nas carreiras de alguns, as práticas paradidáticas remontariam ao trabalho com editoras (Quadro 1). Porém, estruturalmente, ligam-se a um padrão já observado nos anos 1970 , em que o ramo editorial - notadamente as editoras Ática e Abril Cultural - investiu fortemente no filáo paradidático e empregou numerosos indivíduos formados ou trabalhando em universidades paulistas - notadamente, oriundos da USP, da PUC-SP, da Universidade Estadual Paulista (Unesp), da Universidade de Campinas (Unicamp) e da Faculdade Getúlio Vargas (FGV) (RODRIGUES, 2018b). A investida foi bem-sucedida e o mercado era promissor, pois resultava da insuficiente cobertura do sistema de ensino básico e superior face às novas necessidades do setor terciário, em plena expansão (MICELI, 2005 , p. 268). Atualmente, como naquela década, a configuração constituída por contratantes, professores-jornalistas/jornalistas-professores e suas clientelas produzem uma versáo popular e comercializável do polo erudito da cultura, largamente difundida, em contraponto a uma visão dos princípios de divisão que os separam dessa mesma cultura.

Olavo une a linguagem popular à alta cultura, no todo e nas partes, variando apenas, de acordo com o formato, a intensidade de cada uma, mas sempre com o poder de educar e divertir ao mesmo tempo os seus milhares de leitores, ouvintes e alunos, e com a coragem de expor ao ridículo a quadrilha de 'intelectuais' que corrompe o país. (BRASIL, 2013, grifos nossos).

O paulistano Demétrio Magnoli, de 49 anos, faz parte de uma categoria de intelectuais - rara no Brasil - que se notabiliza tanto pelo conhecimento acadêmico, como pela habilidade para escrever sobre temas complexos de maneira clara e objetiva. (MAGNOLI, 2008, grifos nossos). 
[...] acadêmico com linguagem de alcance transversal, seu público de palestras compreende empreendedores, sindicatos e federações de empresários e trabalhadores, profissionais liberais, estudantes e todos aqueles que se interessam por política, história, economia e cultura. Informe-se para Palestras, Mediações, Painéis ou Grupos de discussões". (VILLA, 2018b, grifos nossos).

[...] o professor (Leandro Karnal), que tem quase I milhão de seguidores e ganhou fama por abordar de forma clara temas complexos da filosofia, se tornou exemplo do tema [empreendedorismo] sobre o qual refletiu em sua própria obra [...] (KARNAL, 2017, grifos nossos).

Os artefatos publicitários desses produtos (palestras, conferências, aulas, livros, intelectuais, debates, ideias) concorrem para: a) "reforçar a inclinação espontânea de certas categorias de consumidores à alodoxia"; b) introduzir a lógica dos "índices de audiência ou de lista de best-sellers sobre a recepçáo dos produtos culturais” e, c) orientar as escolhas (de editores, de pares do pólo autônomo em dúvida sobre o sentido de sua atividade, ou de pretendentes às práticas artísticas e científicas) para práticas e "produtos menos requintados e mais vendáveis. (BOURDIEU, 1997, p. 111).

Se os bens simbólicos possuem uma dupla face (material e simbólica), o exercício da autoridade intelectual dos professores-jornalistas/jornalistas-professores trabalha para sua própria redução a uma delas, impondo princípios de apreciação e depreciação, conformes à lógica da perda e do ganho econômico.

[...] $~$ Villa, por razões contratuais não pode falar hoje, mas ele fala todas as manhãs na Jovem Pan, todo mundo conhece a sua coragem (...) (VILLA, 2015, grifos nossos).

Lembra aquela última crise, há seis meses, em que tentaram me ferrar, tô ganhando... $40 \%$ a mais do que eu ganhava, e com público maior, tá bom pra você? (AZEVEDO, $2017) .^{14}$

Essa visão positiva de Lúcifer aparece na literatura... "é melhor reinar no inferno do que ser escravo no céu". Essa é uma noção de empreendedor. Prefiro o meu pequeno negócio do que ser (sic) empregado numa grande instituição. $\mathbf{O}$ empreendedor clássico sempre se orgulha do ilícito. Steve Jobs, na sua biografia, conta que criou

14 Encontra-se o mesmo teor na propaganda de curso oferecido por de Olavo de Carvalho. Disponivel em: <https://www.facebook.com/carvalho.olavo/>. Acesso em: 20 set. 2018. 
uma máquina para roubar o sinal interurbano da ATET. Napoleão começou sua carreira como político em 1799, dando um golpe no regime que jurou defender. O empreendedor, o grande líder é louvado porque é alguém que quebra as regras, inclusive as leis, aceitas pelo grupo. Lúcifer é o primeiro empreendedor de todos os tempos porque saiu da caixinha. Lúcifer é o sonho do RH, né? (risos). (KARNAL, 2017, grifos nossos).

Se as demandas da clientela entram em sintonia e tensão com as demandas desses intelectuais (episódios 3, 4), seus contratantes e as cesuras da economia dão forma mercantil ao conteúdo ideológico do trabalho paradidático. Cumpre sublinhar que a combinação - exemplarmente manifesta na "apresentação" de Lúcifer, acima - entre princípios de transgressão vagamente vanguardistas (ser "louvado" porque "quebra regras") em conformidade à lógica mercantil ("sonho do RH”) e em contrariedade aos conteúdos políticos progressistas ("politicamente corretos”) não é excepcionalidade, mas corresponde a uma tendência. Trata-se de um denominador comum ao conjunto - pois, partindo de um acordo discursivo a respeito da "hegemonia cultural de esquerda" (SCHWARZ, 1970), é possível apresentar-se como um derrotado rebelde, transgressor, que "quebra a regra sendo de direita”, espécie de fiador de rebeldia e desobediência. ${ }^{15}$

Observa-se a construção social, e a credibilização da autoridade intelectual, de um tipo capaz de conciliar atributos inconciliáveis segundo as regras do campo científico ${ }^{16}$. Tanto a interdependência quanto a diferenciação entre o espaço ampliado e o espaço restrito da produção acadêmica são intensificadas pelo tipo de intercâmbio estabelecido entre os dois polos incarnados por essas figuras. Indubitavelmente, “[...] o mais importante

15 Os "fluxos" (Williams, 20I6), juntamente com as combinações indicadas - emulação (discursiva) do polo de produção restrito (plural majestático) em circulação ampliada; arremedo de vanguarda na imposição da apreciação da irreverência e ironia das regras e de si mesmo ("diagnóstico chique"); "quebra de regras" (ser de direita), em conformidade com os princípios do mercado econômico e em contrariedade com os principios do mercado das trocas simbólicas (que consistiria em denegá-lo, isto é ser "politicamente correto", por exemplo, feminista) - são cabalmente encontrados na página da FSP. O texto de Pondé é obrigatoriamente lido em paralelo a propaganda (que por sua vez mescla a "Liuraria da Folha" - anunciando liuros do próprio Pondé - à festa do carnaval). (PONDÉ, 2017).

16 Espera-se que o andamento da análise evidencie que esta assertiva não implica afirmar que os agentes situados no campo científico sejam, em unissono e homogeneamente, portadores de princípios científicos autônomos. Nos interstícios disciplinares e posicionais forjam-se agentes predispostos a gradientes de heteronomia até o limite da batida em retirada do espaço da produção restrita. 
é o fato de que estes dois campos de produção [restrito e ampliado], por mais que se oponham, tanto por suas funçôes como pela lógica de seu funcionamento, coexistam no interior do mesmo sistema." (BOURDIEU, 2003, p. 143). É, portanto, a dimensão sistêmica que importa caracterizar. As próximas seções se dedicam a ela.

\section{Injúria e silêncio: a produção social do pária}

Episódio 6. Demétrio Magnoli e Marilena Chauí. Em junho de 2005, o Deputado Federal Roberto Jefferson denunciou o pagamento de mesadas pelo PT, para a conquista de maioria de votos no Congresso Nacional. Iniciava-se o "escândalo do Mensalão", que retirou um atributo simbólico positivo e exclusivo do PT, tal como assinalado numerosas vezes pela filósofa petista e professora da USP, Marilena Chauí: [...] uma coisa nunca foi posta em dúvida, à direita, à esquerda, pelo centro [...] é a honestidade de um governante petista, e a maneira como ele trata a coisa pública, [...] [a] marca petista [é] a honestidade política [...] (CHAUÍ, 1999, grifos nossos).

A filósofa Marilena Chauí, diante da denúncia, não defendeu nem criticou o partido. Meses antes, o ciclo anual de palestras preparado por Adauto Novaes, do qual a ela participa habitualmente, tinha sido intitulado "Silêncio dos Intelectuais" (NOVAES, 2006). Como de praxe, o título aludia a um tema abrangente e neutro, a que fossem suscetíveis fraçôes cultivadas do público alargado. Porém, a discussão proposta pelo ciclo alterou-se com o advento do "Mensaláo". A obrigatoriedade de reaçáo foi imposta aos intelectuais petistas pela imprensa em alinhamento com seus rivais (intra e extra campo acadêmico). De Marilena Chauí, a tomada de posição foi tanto mais cobrada quanto mais ela foi capaz de afirmar que nada declararia a respeito na grande imprensa. Ao final de agosto do mesmo ano, a filósofa enviou uma "Carta aos alunos", na qual discutia seu "suposto silêncio". No mês seguinte, sem que ela fosse consultada, a FSP publicou o texto da carta, com o seguinte título "Em carta a alunos, Chauí explica seu silêncio" (CHAUÍ, 2005). Entre os meses de agosto e outubro, todas as palestras do ciclo - realizadas em São Paulo, Rio de Janeiro e Minas Gerais - foram noticiadas pelo jornal, que voltava sistematicamente ao "silêncio de Marilena Chaû"” 17 . Armou-se o cenário em que Demétrio

17 O "silêncio de Marilena Chaui" foi explorado quase diariamente. Naqueles meses, o jornal fazia falar seu rechaço à tomada de palaura. O caso se espraiou a outros cadernos, que tratam da Filosofia como curso 
Magnoli golpeou a hierarquia legítima entre as disciplinas e os espaços: na qualidade de geógrafo/articulista da FSP, opóe-se à filósofa-professora da USP.

A “intelectual orgânica do PT não está em silêncio. A pretexto de criticar a mídia... (ela) oferece a história de um complô orquestrado desde a posse de Lula... Entre a filosofia e a ideologia, Chauí optou pela segunda, renunciando à crítica política e emprestando sua autoridade intelectual à estratégia da negação... numa polêmica com José Arthur Giannotti, em 200 I, a filósofa escreveu que, "ao desqualificar os partidos políticos e a imprensa, Giannotti desqualifica politicamente algo mais profundo: a sociedade civil e o conjunto dos cidadãos". O que mudou? O governo Lula começou em 2003. (MAGNOLI, 2005, grifos nossos).

A denegação da glória mundana - típica do universo mais restrito da produção simbólica, organizado segundo o interesse pelo desinteresse (BOURDIEU, 1996) - é dispensada na confessada ambição de se elevar ao cenáculo mais gabaritado, cristalizado na oposiçáo entre as posiçóes estruturantes do campo filosófico: Giannotti e Chauí (RODRIGUES, 2012), que incarnavam, em anos anteriores, na própria FSP, a estruturação partidária estabelecida desde a redemocratização: respectivamente, tucanos e petistas. Magnoli construía uma posição face à conjuntura do rearranjo topográfico partidário, e sua correlata divisão do trabalho de dominação, aproveitando a estrutura do espaço de interseção, construído em fase anterior, pela imprensa, pela USP e por intelectuais de partido (a ela atrelados). A estrutura da configuração, em que outrora PT era oposição e o PSDB, situação, manteve-se, com sinais invertidos e reviravoltas das posiçóes disponíveis aos seus porta-vozes. Ademais, a estratégia de desqualificação propriamente intelectual de adversários mais prestigiados, recurso mobilizado intensamente pelos jornalistas-professores, também estreia neste episódio: "entre a filosofia e a ideologia', a filósofa ficou com a segunda - pecado capital, e a alusão ao sucesso editorial de $O$ que é ideologia, livro de Marilena Chauí - decerto não passou despercebido (sem prejuízo para leitores mal informados a respeito disso).

universitário ("Filosofia ainda é curso desconhecido", 15/1//2005) e chegam a elaborar um quadro "Saiba mais", apresentando quem é "Marilena Chaui" ("Saiba mais", 13/09/2005). Para fazer a filósofa falar em silêncio, a FSP chegou a inquirir seus pares e publicou a enquete: "Intelectuais rejeitam 'silêncio' de filósofa" ("Intelectuais rejeitam 'silêncio' de filósofa", 25 ago. 2005). 
A filósofa não voltou a escrever ou a responder o jornal. Depois de estrelar a bravata contra Chauí, Magnoli estabeleceu-se no novo mercado de reaçóes, com a publicação de Uma gota de sangue: história do pensamento racial (2009) - opondo-se às cotas raciais na universidade pública, e, posteriormente, às ações afirmativas em geral.

A injúria de Magnoli e o silêncio de Chauí são o protótipo da relação entre os intelectuais do mercado de reaçóes e os intelectuais acadêmicos, por eles eleitos como rivais (Quadro 1) - estes últimos recusam-se a entrar em relaçáo com eles, entre outros motivos, por sentirem-se indignos ao fazerem-no. Sistematicamente, ignoram os ataques e só entram em diálogo se a circunstância exigir que respondam, isto é, caso se alcance o limite em que a assimetria dos recursos simbólicos, a eles favoráveis, seja ameaçada (em lógica oposta à dos jornalistas, que reagem sem mediação, pois imediatamente atingidos). Isso ocorre quando o fiel da balança simbólica, móvel último da competição de qualquer controvérsia, é atingido: os estudantes (GINGRAS, 2014). A carta de Marilena Chauí foi instada pela campanha da imprensa por sua tomada de posição e pela difamação contra ela. Porém, a filósofa se dirigiu a seus alunos, potenciais leitores da FSP - e não à imprensa ${ }^{18}$. Dispondo de recursos inequivalentes em escala, o polo erudito trabalha para manter o monopólio do arbitrário cultural e a elevação de suas práticas, demarcando fronteiras:

Por que vocês não contatam o Marco Antonio Villa? Tem um vídeo no Youtube sobre café no Vale, no qual sou 'entrevistado' por ele. Na sessão de uma hora de duração, o cara dormiu metade do tempo... o perfil dele cai muito bem na atual linha editorial da Folha, do Globo, da Veja, provocou. (MARQUESE, historiador e professor da USP, 2016). ${ }^{19}$

18 Em outra modalidade de recusa dialógica, Vladmir Safatle, igualmente filósofo uspiano, deu suas razões para não responder às diatribes de Reinaldo Azevedo (em similar posição à de Magnoli, no episódio 6 - jornalistaprofessor). Ele exprimiu de modo cabal a assimetria de que depende sua posição, e que sua "não resposta" trabalha para manter, circunscrevendo a fronteira que o separa do adversário, isto é a vulgaridade do interesse filistino: "tudo o que se pode desejar (...) é que seu riso seja bem pago." (SAFATLE, 20II).

19 A capacidade de impactar o mercado de reações que estão laborando para construir é inversamente proporcional à de afetar seus pares - embora, a médio prazo, e potencialmente, logrem atingi-los por meio da concorrência da credibilidade que a clientela estudantil confere ou não a eles (BOURDIEU, 1997). Não surpreende que sejam pouco lidos, citados ou resenhados pelos antigos pares do métier; posto que também eles deixaram de atinar para a agenda de suas áreas de origem, orientando-se para a conjuntura política imediata ou pela rentabilidade do mercado editorial (Quadro I). Desse modo, dependem da cobertura da TV Cultura, da FSP, da Liuraria Cultura (em São Paulo e Rio de Janeiro), da ida a talkshows, e da autodivulgação nas páginas 
O episódio 6 apresenta de modo entrelaçado a hierarquia simbólica atiçando as ambições de Magnoli - e os fatores políticos que condicionam sua dupla tomada de posição - contra Marilena Chauí e contra o PT. Vale retomar o episódio 3 (em que Pondé empenha-se em construir sua distância em relação a Bolsonaro). Ele foi instado a "prestar contas" a respeito do que seria a realização prática de suas investidas contra a pauta das minorias (a eleição de Bolsonaro), porém o móvel último delas não é a política partidária:

O debate sobre sexo ficou nas mãos de mulheres que tiveram poucas experiências na vida sexual ou muita falta de sorte na vida afetiva e chegaram à conclusão de que todos os homens eram péssimos. Os homens heteros sempre ficam de fora do debate acadêmico, que é dominado por gays ou feministas. (PONDÉ, 2015, p. 34, grifos nossos).

Náo poderia haver confissão mais precisa do empuxo para a tomada de posição ideológica: sua posição profissional. É consistente a perspectiva teórica segundo a qual as tomadas de posição dos intelectuais só podem ser compreendidas se inscritas num sistema de oposiçóes internas ao campo intelectual - sem que isso implique ignorar as múltiplas modalidades por meio das quais ele se protege ou se torna permeável a agentes, práticas e princípios heterônomos (políticos e/ou econômicos) (SAPIRO, 2003; SAPIRO; MATONTI, 2009; DELPORTE, 2016; BOURDIEU, 1991). Por seu potencial heurístico, nela se baseou o exame acima e o enquadramento estrutural a seguir.

\section{Efeitos de campo e formas de conservadorismo}

As posiçóes rivais, complementares e interdependentes figuradas pelo trabalho no polo de produção restrita e no polo de produção ampliada são subjacente aos litígios expostos. De um lado, situam-se (a) os jornalistas-professores/professores-jornalistas, que trabalham na/para a indústria cultural e constituíram o mercado de reaçóes em questão. De outro, (b) acadêmicos de diversas áreas das humanidades, que exercem magistério e pesquisas, em instituiçóes de ensino e ciência, preferencialmente públicas

pessoais da web. Ser citado por uma personalidade politica agrega-lhes valor: Fernando Collor de Mello citou Marco Antonio Villa; Jair Bolsonaro citou Olavo de Carvalho. 
(Quadro 1). Os dois segmentos correspondem ao esquema segundo o qual, desde os anos 1970, há uma "segmentação irreversível no mercado de bens culturais". Enquanto o capital estatal intervém de modo consistente "sobre os rumos da atividade intelectual e artística erudita" (b), deixa para a iniciativa privada "gêneros e veículos mais rentáveis como 'reserva cativa." (a) (MICELI, 1984, p. 101).

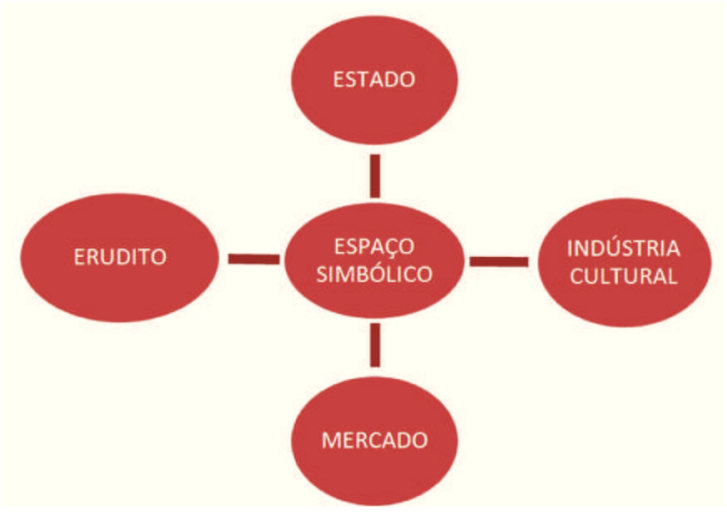

O tipo bem-sucedido das posiçóes dominantes do primeiro polo (a) náo corresponde ao perfil dos jornalistas-professores/professores-jornalistas. Nesse espaço, como em outras práticas simbólicas, com capitais específicos, e hierarquia interna segundo a qual se produzem suas elites, o modelo de excelência seria o jornalista de formação, exerce sua profissão em ramo especializado (reportagem, crítica, telejornalismo) - preferencialmente o articulismo político (NIEMIETZ, 20 I7; BERGAMO, 2006; CHIARAMONTE, 2015). No entanto, tal qual os demais campos, circundam as posiçóes dominantes, em margens dominadas, filóes de praticantes híbridos, com procedências diversas. Infere-se, a partir dos poucos trabalhos disponíveis, que os jornalistas-professores não eram descapitalizados, mas também não ocupavam posições dominantes no campo do jornalismo. Todavia, esses jornalistas-professores também foram produzidos pela dinâmica desse espaço, permitindo o ingresso e a instalação, ao lado deles, dos professores-jornalistas - que também não correspondem ao tipo bemsucedido das posiçóes dominantes de seu espaço profissional originário. 
Estes últimos desvencilharam-se do segundo polo (b), no qual as transformaçóes ocorridas desde os anos 2000 tenderam a sedimentar um espaço competitivo e hierarquizado - levando às últimas consequências as tendências seguidas reconfiguração das ciências sociais, desde os anos $1970 .{ }^{20}$ Essas mudanças deram origem a pelo menos três posições, distribuídas segundo disposições, gerações intelectuais e dotação de recursos inequivalentes: (i) seniors, em fase final de carreira, gozando de raro acúmulo de trunfos temporais (institucionais) e espirituais (reconhecimento intelectual) (RODRIGUES; HEY, 2017); (ii) jovens produtivos e competitivos, em docência e pesquisa, já saídos da fase inicial mas não alçados à consagração na carreira; (iii) seniors e jovens pouco competitivos em termos de pesquisa, mas ativos (e, por vezes, produtivos) em tarefas didáticas - portanto, mais dispostos, à introdução de princípios heterônomos no funcionamento do espaço científico (BOURDIEU, 1996; RODRIGUES, 2018a). Em razão de variáveis como região geográfica da instituição de trabalho e de titulação, sexo, idade, disciplina, disposição para participação política e busca de compensaçóes (econômica e simbólica) em outros ramos de atividade - a distribuição inequivalente de poderes segmentou essas posiçóes básicas; e, no que tange à terceira, inclinou-a a orientaçôes tanto à esquerda quanto à direita (RODRIGUES, 2018a).

Situados nessa terceira posição no espaço acadêmico, os professoresjornalistas em questáo desvencilharam-se desse espaço e de seus princípios competitivos. Objetivamente, a rota para se tornarem seniors consagrados foi bloqueada pela mudança recente dos termos da competição e eles náo foram capazes de se adaptar ao perfil e ritmo produtivo dos jovens (e tampouco mobilizar as estratégias adaptativas dos seniors que as protagonizaram, no manejo dos poderes temporais disponíveis). ${ }^{21} \mathrm{O}$ ingresso na

20 Ainda que se careça de uma análise de fôlego da estruturação, dinâmica e posições disponíveis para o campo científico das ciências humanas, dos anos 1970 aos 2000; é possivel esquadrinhar o espaço, tal com se faz anteriormente, por meio das inferências que se faz a partir de relatórios e estudos setorializados (MICELI, 1993. 1995; FIGUEIREDO, 1988; FORJAZ, 1989; CANEDO, 2015; MARTINS, 2005).

21 A avaliação dos currículos realizou-se segundo os critérios em vigência no mercado acadêmico: publicação (contínua) de artigos em revistas bem ranqueadas; bolsas de financiamento das agências (Fapesp. Capes, CNPq), para alunos e projetos institucionais; nota dos programas de pós-graduação em que trabalham; $e$, naturalmente, a cobiçada bolsa de produtividade CNPq. A título de ponderação: o artigo com revisão por pares é a forma por excelência da competição restrita intrapares, na fase produtiva da carreira. Naturalmente, 
indústria cultural interrompeu a já minguada produção de artigos científicos, e, concomitantemente, multiplicou conferências, palestras, vídeos, áudios, plateias - indicador irrefutável da batida em retirada do campo intelectual em sentido estrito. Embora pouco competitivos, como pesquisadores, eles não eram improdutivos em tarefas didáticas. Além de atraírem um número elevado de alunos, alguns se dedicavam à produção de materiais didáticos e paradidáticos, com regularidade. Enquanto essa condição - investimento sem compensação e reconhecimento - os impulsiona a desprenderem-se do campo acadêmico, a abertura de oportunidades na indústria da informaçáo e do entretenimento os encoraja a explorá-las. A competência reprodutiva e didática - em detrimento da produtiva/inovadora/científica - tornou-se um handicap no mercado acadêmico das duas últimas décadas; porém, eles a converteram em trunfo nos espaços da indústria cultural, que lhes exige precisamente, em ritmo intenso, a repetitividade/didática, a linguagem não especializada/científica (mas "acessível”). Ademais, o trânsito entre espaços relativamente autônomos implica mobilidade entre hierarquias com princípios diversos. Assim, se ocupavam posiçôes simbolicamente rebaixadas ou pouco competitivas; na indústria cultural, inversamente, eles "ingressaram por cima”, situam-se na posição mais elevada/intelectualizada do polo ampliado e na posição mais rebaixa$\mathrm{da} /$ didático, do polo acadêmico. ${ }^{22}$

Situados às margens do polo erudito/restrito/acadêmico, fonte da autoridade intelectual legítima, o princípio gerador da fórmula de seu "antipetismo" produz-se contra as razóes às quais atribuem o malogro simbólico de que padecem. Ao insistirem em que a cultura legítima seja "de e/ou a da esquerda" não estão exprimindo a dominação que esta logra imprimir a eles, mas a posição objetivamente dominada que ocupam em relação a toda a constelação mais prestigiada e mais recompensada (simbolicamente), à qual não pertencem. Essa condição torna inteligível o princípio de eleição dos "rivais eleitos".

os consagrados e os seniors dispõem de recursos que lhes permite contornar essa competição, dispensando-os dela (como: assento e participação em comitês de agências públicas e privadas de fomento, avaliação e regulação, cargos consultivos nas associações profissionais, em editoras universitárias prestigiadas, em periódicos acadêmicos etc.). Essa observação que interessa ao argumento seguinte.

22 Nela, a balança simbólica pende favoravelmente ao jornalismo impresso e televisivo, detrimento da teleficção e dos programas de auditório (BERGAMO, 2006). 
Trata-se de figuras "hegemônicas" não no polo de produção restrita - ao qual os professores-jornalistas não pertencem mais e ao qual os jornalistasprofessores ambicionam pertencer (episódio G) - mas no polo de produção ampliada. Efetivamente, os lados dos litígios (episódio G) se diferenciam em torno do que os une: o pendor à heteronomia e ao polo ampliado da produção. Os "rivais eleitos" também se fizeram voltando-se para o circuito ampliado de produção, ainda que, diferentemente deles, tivessem por plataforma o partido (e não a indústria cultural). ${ }^{23}$ Os marxistas, por exemplo - alvos preferenciais de Villa e Pondé, que não nomeiam seus adversários, como Carvalho, Azevedo e Magnoli - padecem, tal qual seus inimigos em tela, de posiçóes dominadas. Daí desenvolverem estratégias alternativas de sobrevivência institucional e simbólica - dentre elas, tentarem posicionarse em relação à emergência desses intelectuais (RODRIGUES, 2018 a). Tudo se passa como se sentissem a ameaça de concorrência pela clientela estudantil inclinada à participação política.

Ao tomarem os dominantes da produção ampliada como "os" dominantes da ordem simbólica, os jornalistas-professores/professores-jornalistas demonstram que o estado das lutas do campo científico incorporado por eles corresponde a um tempo pretérito. E, sendo atiçados a denegar a ordem das coisas que os denegou, tomando por dominantes do campo restrito, intelectuais de visibilidade no espaço da produção alargada, eles se revelam táo propensos à alodoxia quanto suas freguesias. Nada seria mais equivocado do que indicar esse equívoco, pois, na prática, trata-se de outro trunfo: é a pedra de toque para o enlace vibrante da conquista de fấs/ seguidores/leitores/alunos. Afinal, os "rivais eleitos"são figuras conhecidas

23 Como o episódio mais estratégico para reconstituir o mercado das reações apresentou no centro dele a figura de Marilena Chauí, sua trajetória tornou-se paradigmática para sistematização apresentada nesta passagem. Contudo, vale a ressalva: em prol da caracterização da gênese estrutural e da dinâmica do mercado de reações, neste artigo, assim como não se deteve nos públicos diferenciados e tampouco nas trajetórias particulares dos intelectuais da indústria cultural não é possivel apresentar as posições inequivalentes que os intelectuais petistas lograram conquistar em suas respectivas disciplinas acadêmicas. Indiscutivelmente, Chaui ocupou posições dominantes no espaço restrito e ampliado; contudo, avaliados coletivamente, os intelectuais (petistas, de esquerda, marxistas) não cumpriram o mesmo destino bem-sucedido. Dai serem situados de maneira próxima, pela inclinação à heteronomia, pelas posições dominadas que ocupam no campo acadêmico. Cumpre a ressalva: afirmar que o polo ampliado destes rivais não tinha esteio na indústria cultural não significa ignorar que eles tenham participado dela - seja como colaboradores dos ramos editoriais paradidáticos seja na militância em jornais alternativos, durante os anos 1970 e início dos 1980 (ALMEIDA, 1992; RODRIGUES, 2018 b). 
da freguesia, tornando-se o elo entre a vibração dos dois lados, unidos contra a ordem simbólica legítima que os deslegitima. A alodoxia convergente de jornalistas-professores/professores-jornalistas e suas clientelas garante o sucesso nos espaços da indústria cultural, assim como atenua a violência a eles dirigida pelos pares efetivamente dominantes (posto que lhes escape quem são os pares produtivos/competitivos, que efetiva e objetivamente os jogaram para o escanteio da competição).

As posições objetivas correspondem a fórmulas discursivas de conteúdo ideológico e uma delas é comum a todos: o antipetismo. Ele consiste na contraposição às gestóes petistas, como uma catapulta para tomadas de posição em matéria de educação e cultura, permitindo que emitam juízos a respeito da hierarquia cultural legítima e rechacem a ordem simbólica que simultaneamente os destituiu de reconhecimento e consagrou "todos" os outros.

[...] é uma exceção na academia. Ao contrário da maioria de seus pares nas ciências humanas, Villa é um crítico duro das práticas do PT. (VILLA, 20I3, grifos nossos).

Mais doloroso ainda, porém, foi descobrir que todos os mestres-pensadores e líderes políticos que encarnavam os ideais pomposamente alardeados pela militância intelectual esquerdista - todos, sem exceção... foram indivíduos sádicos, obsessivamente mentirosos, aproveitadores cínicos, vaidosos até a demência ... (CARVALHO, 2013, p. 138, grifos nossos).

[...] o filme submete a um justo ridículo a sociologia vagabunda que tenta ver a polícia e o bandido como lados opostos (às vezes unidos), mas de idêntica legitimidade, de um conflito inerente ao estado burguês. O kantiano rústico "pegou geral" o Bonde do Foucault. (AZEVEDO, 2007, grifos nossos).

O sucesso da mensagem pressupóe clientela com demandas equivalentes às que os levam a ofertar tais reaçóes. Esse encaixe se estabelece pela homologia estrutural das respectivas posiçóes dominadas em relaçáo aos dominantes de seus espaços. A atração entre a clientela e esses intelectuais se funda na contraposiçáo à ordem simbólica que os privou de reconhecimento (equivalente aos que acreditam que os seus adversários desfrutem). Em função dos benefícios materiais e simbólicos dos quais foram despossuídos, sua posição os insta a tomar todos os intelectuais (em posiçôes distintas das suas) como dominantes e adversários. E, como 
estes o são, efetivamente, em relação aos professores-jornalistas/jornalistas-professores, embora não o sejam no campo de produção restrita - o encaixe da rejeição tem a aparência de necessidade. Eis a razão pela qual a inversão da hierarquia simbólica por meio das "denúncias" de fragilidade e incompetência intelectual de autoridades, da falência das instituições de saber, são fortemente instadas e tão bem recebidas. Sendo injusta a ordem que consagrou os "rivais eleitos", faz sentido que jornalistas-professores/professores-jornalistas e suas clientelas compensem seu malogro nas posições rebaixadas na hierarquia simbólica, denunciando a injustiça, o absurdo e a relatividade dessa ordem.

Olha, tem gente que trocou não sei quantos passaportes, mas não escreve livro... tem gente que ganha bolsa para fazer lua de mel... (VILLA, 2008, p. 31, grifos nossos).

[professores] são pessoas que (...) têm uma inteligência mediana e foram, quando jovens, alunos medíocres, que fizeram ciências humanas porque sempre foi fácil entrar na faculdade em cursos de ciências humanas. (...). Toda forma de totalitarismo (o politicamente correto é uma forma de totalitarismo) (...) sobrevive graças às hordas de inseguros, medíocres e covardes que povoam a educação e o mundo da cultura e da arte... na universidade (a mediocridade) vem vestida de burocracia da produtividade e corporativismo de bando... Talvez não exista universo menos ético que o da cultura, da arte e da educação, mas graças a Deus ninguém sabe disso... (PONDÉ, 2014, p. 42-50, grifos nossos).

As frustraçóes em sintonia, orientadas à mesma direção - posiçóes dominadas/ambiçôes dominantes; desejo de dignificação - promovem um encaixe na construçáo de um espaço próprio para vigência da hierarquia invertida (em relaçáo ao espaço social mais amplo), mas de assimetria inequivocamente reposta (a clientela se torna fã/seguidora/leitora/admiradora dos doutrinadores). Daí suas mensagens serem simultaneamente culturais e políticas, submetidas à performance de inversão da hierarquia vigente nos dois âmbitos (Estado/PT, ordem simbólica/intelectuais em geral e petistas em particular). Essa inversão atende às demandas simbólicas tanto dos jornalistas-professores/professores-jornalistas (dominados simbolicamente, acumulando capital econômico) quanto de sua clientela cativa (destituída de capital cultural legítimo, em busca de dignificação). Em política, o petismo e o "politicamente correto", é apresentado como dominante, e conta 
com a posição objetiva do PT no governo - ensejando todas as oportunidades para oposição incondicional a ele. Em cultura, o repertório de ideias, causas, símbolos da esquerda (revoluçáo comunista, feminismo, minorias, etc. - sem diferenciá-los). Trata-se de uma fórmula discursiva de "antipetismo” duplamente eficaz, pelas inversóes que possibilita (política/cultura).

\section{Moral da história: uma revolução conservadora}

Adotando uma perspectiva atenta à interdependência entre os polos que rivalizam pela imposição do arbitrário cultural, este texto procurou caracterizar a dinâmica de um "mercado de reaçôes" políticas constituído em função de alteraçôes morfológicas no campo político e cultural. Na esfera cultural, oportunidades inéditas foram criadas para os intelectuais que desqualificam o PT, pois puderam tomar as posiçóes outrora ocupadas pelos seus adversários petistas - notadamente, as de vigilância moral e combate ideológico aos grupos dirigentes. Não se originando da lógica nem dos interesses específicos do espaço partidário; o antipetismo dos intelectuais não encontra neles seu princípio gerador de reaçôes e fórmulas discursivas. Os móveis, os interesses e os recursos específicos da disputa simbólica condicionam e distinguem sua maneira de opor-se ao PT.

O material e a reconstituição sociológica das interações permitiram surpreender a tendência à forma mercantil do conteúdo ideológico do trabalho paradidático realizado pelos intelectuais. Importa salientar a similitude entre a lógica do mercado de reaçóes em exame a revoluçáo conservadora promovida pela sobredeterminação econômica do princípio cultural no mundo das ediçóes, tal como Pierre Bourdieu (1999) identificou. Nela, como no caso em tela, são tangíveis os efeitos de histerese que conduzem a receber como transgressões avançadas oposiçóes que correspondem ao modus operandi do mercado econômico, e, sobretudo, a ele subordinadas. Marcelo Ridenti já assinalou, ao analisar "o momento da consolidação da cultura de massa e da indústria cultural"no País, que a "não profissionalização dos meios intelectuais e artísticos"e a frágil constituição dos polos autônomos de produção permitiu que se intercambiassem técnicas, repertórios, quadros e critérios de um espaço a outro (RIDENTI, 2014). A demanda/oferta acima permitiu também que numerosos antigos militantes 
de partidos revolucionários transportassem seus repertórios para a televisão e outros espaços da indústria cultural - ao serem empregados por ela nas fases iniciais de seu estabelecimento (RODRIGUES, 2010; GOLDENSTEIN, 1987). Enquanto a indústria cultural não contava com uma formação própria de quadros especializados, aproveitava profissionais formados em espaços alheios e relativamente opostos a ela - em termos ideológicos. Eles eram encarnaçóes de uma dissonância: "apesar da ditadura de direita, há relativa hegemonia cultural de esquerda no país." (SCHWARZ, 1970, p. 62). ${ }^{24}$

Este trabalho interpela discussóes acumuladas pela sociologia dos intelectuais e pela sociologia da cultura, de verve frankfurtiana e bourdiesiana, a respeito da indústria cultural (MICELI, 1984, 2005; ARRUDA; GOLDENSTEIN, 1975; ORTIZ, 1988; RIDENTI, 2014; ROCHA, 2011).

Sergio Miceli identificou três vertentes argumentativas nas pesquisas sobre intelectuais brasileiros: a sociológica culturalista; a doutrinário-politicista; e a organizacional-institucionalista (MICELI, 2001. As posiçóes antagônicas das duas primeiras e as contribuiçóes que a terceira oferta a ambas apresentaram, desde então, momentos de polêmica. Contudo, as pesquisas não se desvencilharam dessas três linhagens - particularmente no que elas apresentam em comum, a despeito das divergências que as apartam: a predileção conjunta por tempos remotos, dentro da qual ocorre uma tácita divisão social do trabalho de pesquisa, combinando períodos

24 A tentação de invertê-lo - "temos governo de esquerda e hegemonia cultual de direita" - resolve um desencaixe semi-lógico, mas é inócua - razão pela qual a análise procurou enfatizar os espaços de produção e consumo da cultura, seus segmentos e suas inclinações. Durante décadas, esse diagnóstico não foi colocado em dúvida e os estudos a respeito de cultura e política partiam dele para análises de conteúdo circunscritas dos gêneros (literatura, música, teatro, cinema), nele tratados conjuntamente e sob a orientação da análise formal. Ademais, os princípios de apreciação e juizo vanguardistas emitidos por Roberto Schwarz foram incorporados conjuntamente com seu veredito, orientando a escolha de objetos e as análises dos mesmos, assinalando a afinidade de gosto entre ele e o campo cultural em que foi vencedor. Assim, embora em uníssono se afirme que direita e esquerda são termos relacionais e conflitivos, essa petição de princípio não desenhou as pesquisas. Logo, sabe-se pouco a respeito da produção intelectual e artística concomitantemente à direita e à esquerda. Compartilha-se, em geral a opinião de que a direita não está à altura da produção simbólica produzida pela esquerda - sem se indagar a respeito das condições objetivas que tenham contribuído favoravelmente para a superioridade deste patrimônio cultural - particularmente, o mesmo ocorre com a hierarquização do marxismo em relação a outras correntes teóricas, de cuja gênese já se tratou (RODRIGUES, 20I2). Em um cenário em que a disputa se polariza e se determina reciprocamente parece mais interessante a análise efetivamente relacional, isto é, indagar contra quem/o quê (e como) tal superioridade cultural se construiu. 
e preferências argumentativas; e a atenção voltada a agentes situados em zonas hierarquicamente superiores da produção simbólica. Desse modo, um conjunto de problemas de pesquisa, polêmicas e métodos circunscreveu a imaginaçáo da área. Enquanto os que se ocupam do "pensamento social"/"pensamento político" apresentam uma inclinação pela história das ideias, e por autores que viveram no século XIX e início do XX; os que se ocupam da história das ciências sociais, ocupam-se menos das ideias e mais dos agentes, voltam-se para a morfologia das instituiçóes de saber, e buscam índices de profissionalização disciplinar. Estes atribuem aos primeiros uma visão encantada e os primeiros lhes imputam uma visão desconfiada dos intelectuais. Ademais, enquanto os que se ocupam de "ideias/pensamento" fazem "análise interna" das obras; os outros, segundo eles, não as leriam/analisariam com devido cuidado. Um balanço recente constatou a vigência ainda hodierna dessa divisa em particular (JACKSON; PRAXEDES, 2017) - que remonta, se bem reconstituída a unidade e a fragmentação das áreas, à rivalidade metropolitana e disciplinar, entre Rio de Janeiro e São Paulo, cidades vocacionadas à ciência política e à sociologia (RODRIGUES, 2017).

A proposta de analisar o "mercado das reaçôes" promove uma reviravolta no objeto "intelectual" expondo impensados dessa área de estudos. Todos os atributos do objeto dessa proposta invertem o sistema de preferências da área: eles atuam no tempo presente, são inexpressivos em suas disciplinas acadêmicas de origem, são destituídos de trunfos que os habilitaria a exercerem funçôes políticas no Estado ou a lhe venderem seus serviços de expertises. As exigências de método decorrentes disso tornam inoperantes as inclinaçóes excludentes da sociologia dos intelectuais (interno/externo; texto/contexto; diletante/profissional; ensaísmo/ciência) pois requer o exame combinado desses âmbitos e a disposição à análise do elemento "público", que raramente é equacionado nesses estudos. Esperase que o desarranjo heurístico delas, tal como se propóe nesta pesquisa, possa alargar a agenda rumo a novos problemas. 


\section{Referências}

ADORNO, T. Introduçáo à sociologia da música. São Paulo: EdUnesp, 2011.

ALMEIDA, M. H. T. Tomando partido, formando opiniáo. São Paulo: Sumaré, 1992.

ARRUDA, M. A. N.; GOLDENSTEIN, G. T. A noite da madrinha: transfiguração simbólica e transfiguração teórica. Novos Estudos Cebrap, São Paulo, v. 11, p. 124-141, 1975.

AZEVEDO, R. Capitão Nascimento bate no Bonde do Foucault. Veja, São Paulo, 17 out. 2007.

Comenta que eu te escuto. TV Folha, 19 dez. 2017. Disponível em: <https://www. youtube.com/watch?v=4FUkmthl3wo>. Acesso em: 2 abr. 2018.

BERGAMO, A. Imitação da ordem. As pesquisas sobre televisão no Brasil. Tempo Social, v. 18, n. 1, jun. 2006.

BOURDIEU, P. A distinção: crítica social do julgamento. São Paulo: EDUSP; Porto Alegre: Zouk, 2007.

As regras da arte. Lisboa: Editorial Presença, 1996.

Sobre a televisão. Rio de Janeiro: Zahar, 1997.

Gênese e estrutura do campo religioso. In:

Economia das trocas simbólicas. São Paulo: Perspectiva, 2003a.

O mercado dos bens simbólicos. In:

. Economia das trocas simbólicas. São Paulo: Perspectiva, 2003b.

Le champ littéraire. Actes de la Recherche en Sciences Sociales, Paris, n. 89, p. 3-46, 1991.

Une révolution conservatrice dans l'édition. Actes de la Recherche en Sciences Sociales, Paris, n. 126-127, p. 3-28, 1999.

BRASIL, F. M. 15 de março: Olavo tem razão. 15 mar. 2017. Disponível em: <https://veja.abril. com.br/blog/felipe-moura-brasil/15-de-marco-olavo-tem-razao/>. Acesso em: 2 jul. 2018.

Apresentação. In. : O mínimo que você precisa saber para náo ser um idiota. Rio de Janeiro/São Paulo: Editora Record, 2013.

CARVALHO, O. O mínimo que você precisa saber para não ser um idiota. Rio de Janeiro/São Paulo: Editora Record, 2013.

CANEDO, L. A Fundação Ford e as Ciências Sociais no Brasil. Paper from Social Sciences and Humanities in the Changing North-South Relations (INTERCO-SSH), Cordoba, 2015.

CHAUI, M. Carta aos alunos. Folha de S. Paulo, 21 set. 2005. Disponível em: <https://www1. folha.uol.com.br/folha/brasil/ult96u72595.shtml >. Acesso em: 2 abr. 2018.

O que é ideologia. São Paulo: Brasiliense, 1980. 
. Entrevista no Roda viva. 1999. Disponível em: <https://www.youtube.com/ watch?v=GvbnN4Difto $>$. Acesso em: 2 abr. 2018.

CHIARAMONTE, A. R. Lutas simbólicas e doxa. 2015. 214 f. Dissertação (Mestrado em Sociologia) - Programa de Pós-Graduação da Faculdade de Filosofia, Letras e Ciências Humanas, USP, 2015.

COMPANHIA PAULISTA DE FORÇA E LUZ (CPFL). 23 out. 2016. Disponível em: <https:// www.youtube.com/watch?v=4Uk1T9ZswUw>. Acesso em: 2 abr. 2018.

CONSTANTINO, R. Villa x Olavo. A importância das narrativas na política. 29 abr. 2015. Disponível em: <http://rodrigoconstantino.com/artigos/villa-x-olavo-a-importancia-dasnarrativas-na-politica/>. Acesso em: 23 jan. 2016.

DELPORTE, C. Une lutte croiassante pour l'attention médiatique. In: CHARLE, Christophe; JEANPIERRE, Laurent. La vie intellectuelle en France de 1914 à nos jours. v. 2. Paris: Éditions du Seuil, 2016. p. 437-461.

DUVAL, J. Critique de la raison journalistique. Les transformations de la presse économique en France. Paris: Éd. Le Seuil, 2004.

EYAL, G.; BUCHHOLZ, L. From the Sociology of Intellectuals to the Sociology of Interventions. Annual Review of Sociology, [S.1.], n. 36, p. 117-137, 2010.

FANPAGE OLAVO DE CARVALHO [2018]. Disponível em: <https://www.facebook.com/ carvalho.olavo/>. Acesso em: 2 abr. 2018.

FIGUEIREDO, M. O financiamento das Ciências Sociais - 1966-1985. Boletim de informação bibliográfica, São Paulo, n. 26, p. 38-55, 1988.

FOLHA DE S. PAULO. Filosofia ainda é curso desconhecido. 15 nov. 2005

Saiba mais. 13 nov. 2005.

Intelectuais rejeitam silêncio de filósofa. 25 ago. 2005.

JAKOBSKIND, M. A. Mentiras e manipulaçóes. 2010. Disponível em: <http://www. institutomillenium.org.br/divulgacao/clipping/mentiras-e-manipulacoes-blog-da-dilma>. Acesso em: 26 abr. 2018.

JOVEM PAN NEWS. Informação, credibilidade e o melhor time do jornalismo. 23 maio 2017. Disponível em: <https://www.youtube.com/watch?v=avLleXGkLR4\&t=1999s>. Acesso em: 2 abr. 2018.

FORJAZ, M. C. S. Cientistas e militares no desenvolvimento do CNPq. Boletim de informação bibliográfica, São Paulo, n. 28, p. 71-99, 1989.

GINGRAS, Y. La dynamique des controverses en sciences sociales et humaines. In: Controverses. Accords et désaccords en sciences humaines et sociales. Paris: CNRS Editions, 2014.

GOFFMAN, E. A representaçáo do eu na vida cotidiana. Petrópolis: Vozes, 2005. 
GOLDENSTEIN, G. T. Do jornalismo político à indústria cultural. São Paulo: Summus, 1987.

GRUN, R. Da pizza ao impeachment: uma sociologia dos escândalos no Brasil contemporâneo. São Paulo: Alameda, 2018.

JACKSON, L. C.; PRAXEDES, D. Histórias das Ciências Sociais Brasileiras. Sociologia Brasileira hoje, São Paulo: Ateliê Editorial, 2017.

HALL, S. Encoding/decoding. In: HALL, S. et al. (Ed.). Culture, media, language. New York: Routledge, 1996. p. 128-138.

HIRSCHMAN, A. O. A retórica da intransigência. São Paulo: Companhia das Letras, 1992.

KARNAL, L. Entrevista. Leandro Karnal. Lúcifer é o primeiro empreendedor de todos os tempos. O Globo, Rio de Janeiro, 8 abr. 2017.

KERTZMAN, R. Um dia triste para a imprensa que presta no Brasil. 2017. Disponível em: <http:// blogs.uai.com.br/opiniaosemmedo/2017/05/23/um-dia-muito-triste-para-imprensa-que-prestano-brasil/>. Acesso em: 2 jun. 2018.

LADEIRA, F. F. Intelectuais midiáticos. ed. 885. Observatório da imprensa. 12 jan. 2016.

LEITE, P. M. A inclinação da imprensa à direita. Blog Pessoal. 4 nov. 2013.

LEITÃO, M. Constantino e Reinaldo emburrecem o país. O Globo, Rio de Janeiro, 3 nov. 2013.

MAGNOLI, D. Uma gota de sangue: história do pensamento racial. São Paulo: Contexto, 2009. Miséria da filosofia. Folha de S. Paulo, São Paulo, 29 nov. 2005.

Uma vitória da razão. Entrevista. Veja, São Paulo, 5 nov. 2008.

MARQUESE, R. Historiador da USP recusa entrevista à Folha: por que não contatam o Marco Antonio Villa? Revista Fórum, Santos, 23 mar. 2016. Disponível em: <https://www.revistaforum. com.br/historiador-da-usp-recusa-entrevista-a-folha-por-que-nao-contatam-o-marco-antoniovilla/>. Acesso em: 20 set. 2018.

MARTINS, C. B. (Org.). Para onde vai a Pós-Graduaçáo no Brasil. Brasília, DF: Capes, 2005.

MICELI, S. Intelectuais à brasileira. São Paulo: Companhia das Letras, 2001.

A noite da madrinha e outros ensaios sobre o éter nacional. São Paulo: Companhia das Letras, 2005.

A aposta numa comunidade científica emergente. In: A Fundaçáo Ford no Brasil. São Paulo: Sumaré, 1993.

O cenário institucional das Ciências Sociais no Brasil. In: História das Ciências Sociais no Brasil. São Paulo: Sumaré, 1995.

Teoria e prática da política cultural oficial no Brasil. In: Estado e cultura no Brasil. (Org.). São Paulo: Difel, 1984. 
NASSIF, L. O caso Karnal-Moro, os intelectuais e as tentações midiáticas. GGN, 15 mar. 2017.

NIEMIETZ, C. L. Nova República, novo jornal. 2017. Dissertação (Mestrado em Sociologia) Programa de Pós-Graduação em Sociologia. USP, 2017.

NOGUEIRA, P. Novos trombones da direita. Revista Época, Porto Alegre, 19 abr. 2012.

Um analfabeto político chamado Kim Kataguiri. Diário do Centro do Mundo, [S.1.], 13 abr. 2015 .

NOVAES, A. (Org.). O silêncio dos intelectuais. São Paulo: Companhia das Letras, 2006.

NUNES. A. Mais uma aula de Marco Antonio Villa: a revolução cultural do PT. Veja, São Paulo, 9 fev. 2017. Disponível em: <https://veja.abril.com.br/blog/augusto-nunes/mais-uma-aula-demarco-antonio-villa-a-revolucao-cultural-do-pt/>. Acesso em: 2 abr. 2018.

ORTIZ, R. A moderna tradiçáo brasileira: cultura brasileira e indústria cultural. São Paulo: Brasiliense, 1988.

PEREZ, Fabiola. Eles fazem a cabeça dos jovens. Istoé, São Paulo, 30 set. 2016. Disponível: <https:// istoe.com.br/mario-sergio-cortella-karnal-e-clovis-barros-filho-fazem-a-cabeca-dos-jovens $>$. Acesso em: 20 set. 2018 .

PINHEIRO, F. O rei do outro pólo: Paulo Coelho na literatura brasileira. In: MICELI, S.; PONTES, H. (Org.). Cultura e sociedade: Brasil e Argentina. São Paulo: Companhia das Letras, 2014.

PONDÉ, L. F. Guia politicamente incorreto da Filosofia. São Paulo: Leya Casa da Palavra, 2014.

Tipologia da direita contemporânea. Folha de S. Paulo, 2 out. 2017.

Jair Bolsonaro e seus eleitores (entrevista na Rádio Bandeirantes). Saber Filosófico. 2017. Canal do Youtube. Disponível em: <https://www.youtube.com/watch?v=me5p3q0JTwQ>. Acesso em: 2 abr. 2018

. Olavo de Carvalho. Canal pessoal Youtube. 6 jun. 2016. 2016a. Disponível em: <https:// www.youtube.com/watch?v=E8kLR4QMDH0>. Acesso em: 11 abr. 2018.

RIDENTI, M. Caleidoscópio da cultura brasileira, (1964-2000). In: MICELI, S.; PONTES, H. (Org.). Cultura e sociedade: Brasil e Argentina. São Paulo: Companhia das Letras, 2014.

ROCHA, M. E. M. Em busca de um ponto cego: notas sobre a sociologia da cultura no Brasil e a diluição da mídia como objeto sociológico. Sociedade e Estado, Brasília, (DF), v. 26, n. 3, p. 453-470, 2011.

RODRIGUES, L. S. Um departamento municipal no ultramar francês: o cosmopolitismo de José Arthur Giannotti. Campos, Curitiba, v. 18, n. 1-2, 2017.

Poder, Sexo e Línguas no marxismo à brasileira. REPOCS, 2018a. No prelo. 
. Centralidade de um cosmopolitismo periférico: a Coleçáo Grandes Cientistas Sociais no espaço das Ciências Sociais brasileiras, (1978-1990). Sociedade e Estado, Brasília (DF), 2018b. No prelo.

Revolução e mercado. Estudos históricos, n. 48, v. 24, p. 437-440, 2010.

A produçáo social do marxismo universitário em Sáo Paulo: mestres, discípulos e um seminário. 2012. 565 f. Tese (Doutorado em História) - Programa de Pós-Graduaçáo em História Social. USP, 2012.

Rivalidades científicas e metropolitanas: Sáo Paulo e Rio de Janeiro, Sociologia e Ciência Política. Urbana, Campinas, n. 18, p. 71-95, 2017.

HEY, A. P. Elites Acadêmicas: as Ciências Sociais na Academia Brasileira de Ciências.

Tempo Social, São Paulo, v. 29, p. 9-33, 2017.

SADER, E. Escribas de aluguel. Blog da Boitempo, 21 ago. 2013.

SAFATLE, V. Sem resposta. Folha de S. Paulo, São Paulo, 22 nov. 2011.

SAPIRO, G. La guerre des écrivains, (1940-1953). Paris: Fayard, 1999.

Forms of politicization in the French literary field. Theory and society, [S.I.], n. 32, p. 633-652, 2003.

Modèles d'intervention politique des intellectuels: le cas français". Actes de la Recherche en Sciences Sociales, Paris, n. 176-177, p. 8-31, 2009.

MANTONTI, F. L'engagement des intellectuels: nouvelles perspectives. Actes de la Recherche en Sciences Sociales, Paris, n. 176-177, p. 4-7, jan. 2009.

SINGER, S. Arena de debates. Folha de S. Paulo, São Paulo, 27 out. 2013.

SCHWARZ, R. Cultura e Política, (1964-1969). O pai de família e outros estudos. São Paulo: Paz e Terra, 1992.

VILLA, M. A. Artigo do Prof. Villa na Istoé: a culpa é da democracia. Será? Blog do Villa. Disponível em: <http://www.blogdovilla.com.br>. Acesso em: 2 abr. 2018.

_ Entrevista. A década petista é a década da falácia. Revista Época, Rio de Janeiro, 15 jul. 2014.

Manifestaçáo Impeachment. Professor Marco A Villa. Canal do Youtube Marcus Cezar Meyer Sukevicius. 13 dez. 2015. Disponível em: <https://www.youtube.com/ watch?v=dGAYBBduexc>. Acesso em: 2 abr. 2018.

Marco Antonio Villa ataca Olavo de Carvalho. Rádio JP. 25 abr. 2015. <https://www. youtube.com/watch?v=v8Lzbkn55KI>. Acesso em: 25 abr. 2015.

Marco Antonio Villa discursa do caminha do Vem pra rua nas manifestaçóes na Av

Paulista. Canal Youtube Qual é a bronca. 2016. Disponível em: <https://www.youtube.com/ watch?v=FuwOLgwLkEo>. Acesso em: 13 mar. 2016. 
VOLPE, M. O divã no palco. 2013. 213 f. Tese (Doutorado em Sociologia) - Programa de PósGraduação em Sociologia. USP, 2013.

WILLIAMS, R. Televisão. Tecnologia e forma cultural. São Paulo: Boitempo, 2016.

\section{A Conservative Revolution of the Intellectuals (Brazil/2002-2016)}

\section{Abstract}

Since 2002, a market of reactions to PT's presidential administrations has been established, through the conventional media merged with the ultra-contemporary and the social production of hybrid intellectuals: they are journalists-teachers and teachers- journalists. This article addresses the dynamics of the exchanges established among the agents in this market. The focus will be on Olavo de Carvalho; Demétrio Magnoli; Marco Antonio Villa; Reinaldo Azevedo; Luiz Felipe Pondé; Rodrigo Constantino; Leandro Karnal. The analysis will be developed in three movements: it will present the classifications, the frameworks and some demands that they have received from opponents, contractors and clients. In order to characterize the principle that generates its political and cultural positions, the article will then carry out the sociogenesis of space and agents resulting from the structuring of the national education and research system as well as the cultural industry since the 1970s. Finally, it will discuss the sociological framework adopted.

Keywords: Intellectual field, Symbolic exchange market, Media, Cultural industry, "New Right”.

Recebido em: 02/07/2018

Aprovado em: 13/08/2018 